\title{
The Effects of Burnout on Organizational Commitment in Logistics Sector
}

\author{
Dursun YENER \\ Beykoz Vocational School \\ of Logistics, \\ Beykoz, İstanbul, \\ Turkey \\ dursunyener@yahoo.com
}

\author{
Kader OSKAYBAŞ \\ Maltepe University \\ Faculty of Economics and \\ Administrative Science, \\ Maltepe, İstanbul, Turkey \\ kaderkara@maltepe.edu.tr
}

\author{
Tolga DURSUN \\ Maltepe University \\ Faculty of Economics and \\ Administrative Science, \\ Maltepe, İstanbul, Turkey \\ tolgadursun@maltepe.edu.tr
}

\begin{abstract}
Burnout is a psychological syndrome that reduces people's motivation, job satisfaction and organizational commitment. People whose jobs are related with human interaction are usually exposed to burnout. In the literature, three dimensions of burnout were defined as emotional exhaustion, depersonalization and reduced personal accomplishment. In this study antecedents (cynicism, role ambiguity, role conflict and organizational justice) and consequences (job satisfaction, organizational commitment) of burnout were determined in logistics sector which has never been analyzed before in Turkey. Sample size of the study was 420 and judgment sampling method was used. As a result, it was found that antecedents of burnout except organizational justice are positively correlated with burnout factors, and burnout is negatively correlated with its consequences.
\end{abstract}

Keywords: Burnout, Cynicism, Organizational Commitment, Job Satisfaction, Organizational Justice, Logistics

\section{Introduction}

The concept of burnout was introduced in the psychology literature in 1970s by Freudenberger (1974) and Maslach (1976). Until recently researches were usually focusing on industrial workers and little attention was paid to social workers in the human service sector (Kristensen et al, 2005). But in recent years, burnout levels of workers in the service sector have started to be the subject of academic researches. The employees in service sectors are often required to spend considerable time with other people. Frequently, the staff-client interaction is centred around the client's current problems (psychological, social, and/or physical) and is therefore charged with feelings of anger, embarrassment, fear or despair (Maslach and Jackson, 1981). Logistics sector is one of these industries that has busy and stressful relationship between employees and clients.

Burnout is defined as a syndrome of emotional exhaustion and cynicism that occurs frequently among individuals who do "people-work" of some kind (Maslach and 
Jackson, 1981). It was considered as a psychological syndrome specific to professionals performing human services or support tasks for other people (Maroco and Campos, 2012). Burnout is associated with negative organizational outcomes such as reduced job performance, absenteeism, turnover intention, lower career satisfaction, and reduced quality of service (Hultell and Gustavsson, 2010; Volker et al, 2010; Adekola, 2012). Burnout arises when there is significant disharmony between the nature of a person's job and the nature of the person doing the job. Burnout is thus not a personal problem; rather, it is a social/environmental problem related to a person's occupation (Kuruüzüm, Anafarta and Irmak, 2008).

Burnout has three distinct dimensions that are emotional exhaustion, depersonalization, and reduced personal accomplishment. Emotional exhaustion refers to the depletion or draining of emotional resources caused by interpersonal demands. It is characterized by a lack of energy and a feeling that one's emotional resources are used up. Depersonalization is characterized by negative and inappropriate attitudes towards customers, frustration, loss of idealism, and withdrawal. A distinctive feature of depersonalization is a perception of customers as objects, rather than persons. Lack of personal accomplishment is the tendency to evaluate one's work with recipients negatively. (Salahian et al, 2012). According to the definition, burnout is characterized by the simultaneous occurrence of all three dimensions (Kristensen et al, 2005).

\section{Antecedents of Burnout}

In the literature, various factors are defined as antecedents of burnout by researchers. One of them is organizational cynicism. Dean, Brandes and Dharwadkar (1998, p.345) defined organizational cynicism as "negative attitudes of individuals towards the organization they are working". Cynicism leads to a decrease in organizational commitment, lower job satisfaction and alienation. Cynical employees believe they were being treated unfairly in the workplace (Karacaoğlu and İnce, 2012). Thus, we have a hypothesis;

$\mathbf{H}_{\mathbf{1}}$ : Cynicism has significant and positive effect on burnout level of workers.

Role conflict and role ambiguity are also correlated with burnout (Salahian et al, 2012). Role ambiguity occurs when individuals lack of clear definition of their role expectations, and the methods to complete their tasks (Tang and Chang, 2010). Role conflict is defined as the difference, perceived by an employee, between job expectations conveyed by multiple sources. An employee who notices inconsistencies between his/her written job description and requests from a manager is an example of role conflict (Low et al, 2001). These two major role stressors are possible antecedents of burnout, so we have two hypotheses;

$\mathbf{H}_{2}$ : Role ambiguity has significant and positive effect on burnout level of workers. $\mathbf{H}_{3}$ : Role conflict has significant and positive effect on burnout level of workers.

Organizational justice, as another antecedent of burnout, refers to employee perceptions of fairness in the workplace. It has shown to be associated with several outcomes such as job satisfaction, intention to turnover, work performance, and organizational commitment (Elamin and Alomaim, 2011). As originally conceptualized by Moorman, organizational justice is a multidimensional construct, which consists of the following dimensions: distributive justice, procedural justice, and interactional justice (Moorman, 1991). Distributive justice refers to the perceived fairness of 
resource allocation in respect to the balance between employees' contributions and rewards (Lee, 2001). Perceptions of distributive justice are based largely on comparisons with others (Greenberg, 1987). Procedural justice refers to employees' perceptions on the fairness of the manner in which the decision-making process regarding the distribution of resources and rewards is conducted (Al Zahrani, 2011). Interactional justice focuses on employees' perceptions about the fairness of the interpersonal treatment received during implementation (Elamin and Alomaim, 2011). It is expected that if organizational justice gets higher, then burnout level will decrease, so we have;

$\mathbf{H}_{4}$ : Organizational justice has significant and negative effect on burnout level of workers.

\section{Consequences of Burnout}

Burnout can lead to a deterioration in the quality of service that is provided by the staff. Burnout seems to be correlated with various self-reported indices of personal distress, including physical exhaustion, insomnia, depression, turnover, and unproductive work behaviours (Maslach and Jackson, 1981; Cherniss, 1992). At the organizational level, the most important manifestations of burnout are lack of job satisfaction and organizational commitment (Salahian et al, 2012). Job satisfaction has been defined as a pleasurable emotional state resulting from the appraisal of one's job (Kumari and Pandey, 2001). Job satisfaction appears to significantly influence how work stress and employee creativity are related (Tang and Chang, 2010). Job satisfaction and burnout are negatively correlated. So we have;

$\mathbf{H}_{5}$ : Burnout level of workers has significant and negative effect on job satisfaction level of workers.

Organizational commitment refers to an attitude that shows the relationship between employee and organization. Bateman and Strasser (1984) define organizational commitment as employee's loyalty to the organization, and aspire to preserve membership. Meyer and Allen (1991) proposed three types of commitment; affective commitment, continuance commitment, and normative commitment. Affective commitment is defined as employee's psychological attachment and involvement to the organization. Continuance commitment is associated with the costs relevant to leaving the organization as employee's feelings to be dependent on the organization. Normative commitment is seen as perceived obligation to remain with the organization. Therefore the hypothesis is;

$\mathbf{H}_{6}$ : Job satisfaction has significant and positive effect on organizational commitment level of workers.

\section{Research Methodology}

The purpose of the study is to determine the factors that affect burnout level of workers, as internal customers, in logistics sector in Turkey. Since there is no academic study about burnout that cover logistics sector, this study can be considered as an exploratory research. The sample size of the research is 420. Judgment sampling method was used to gather data and participation was voluntary. The survey was conducted anonymously and no personal information was collected that could be used to identify any individual. All respondents are older than 18 years old and work logistics companies in Istanbul/Turkey. Data was obtained using a questionnaire which contains 
close-ended questions. The questionnaire form has seven different scales. In order to measure burnout Maslach's burnout inventory (MBI) was used. MBI has 22 items and three different dimensions which are emotional exhaustion, depersonalization and reduced personal accomplishment. According to the MBI manual the three dimensions should be measured independently and are not combined into a single, total score. This means that we have one concept but three independent measures (Kristensen et al, 2005). Role ambiguity and role conflict scales have 14 items and were adapted from Rizzo et all's scale. Job satisfaction scale adapted from Schleicher et al's (2004) job satisfaction scale and has 8 items. Organizational commitment was measured by using a five-item scale developed by Jaworski and Kohli (1993). Organizational justice scale is adapted from Niehoff and Moorman's (1993) scale and has 9 items. Organizational cynicism scale has 7 items. All the questions in seven different scales are in 5-point Likert form. Last part of the questionnaire is about demographic profiles and work experiences of workers of logistics companies. Demographic characteristics of the participants are shown in Table 1.

Table 1: Demographic Characteristics of Participants

\begin{tabular}{|c|c|c|c|}
\hline & & $\mathbf{N}$ & $\%$ \\
\hline \multirow{2}{*}{ Gender } & Male & 228 & 54,3 \\
\hline & Female & 192 & 45,7 \\
\hline \multirow{4}{*}{ Age } & $18-25$ & 144 & 34,3 \\
\hline & $26-35$ & 160 & 38,1 \\
\hline & $36-45$ & 98 & 23,3 \\
\hline & $46-55$ & 18 & 4,3 \\
\hline \multirow{2}{*}{ Marital Status } & Married & 184 & 43,8 \\
\hline & Single & 236 & 56,2 \\
\hline \multirow{4}{*}{ No. of Children } & 0 & 288 & 68,6 \\
\hline & 1 & 84 & 20,0 \\
\hline & 2 & 36 & 8,6 \\
\hline & 3 & 12 & 2,9 \\
\hline \multirow{4}{*}{ Education } & Highschool & 84 & 20,0 \\
\hline & Pre-graduate & 72 & 17,1 \\
\hline & Undergraduate & 240 & 57,1 \\
\hline & Graduate & 24 & 5,7 \\
\hline \multirow{6}{*}{ Monthly Income } & $0-1000$ & 88 & 21,0 \\
\hline & $1001-2000$ & 196 & 46,7 \\
\hline & 2001-3000 & 92 & 21,9 \\
\hline & $3001-4000$ & 20 & 4,8 \\
\hline & $4001-5000$ & 12 & 2,9 \\
\hline & $5001+$ & 12 & 2,9 \\
\hline
\end{tabular}

Table 2 shows the work experience of workers in the current firm, in the logistics sector and finally the total experience. 
Table 2: Work Experience of Participants (in years)

\begin{tabular}{|l|c|c|c|}
\hline & Mean & Minimum & Maximum \\
\hline Total experience & 8,6 & 1 & 37 \\
\hline Experience in logistics sector & 6,7 & 1 & 30 \\
\hline Experience in current firm & 4,6 & 1 & 30 \\
\hline
\end{tabular}

\section{Research Model}

After reviewing the relevant literature, the research model which is seen in Figure 1 was prepared by researcher.

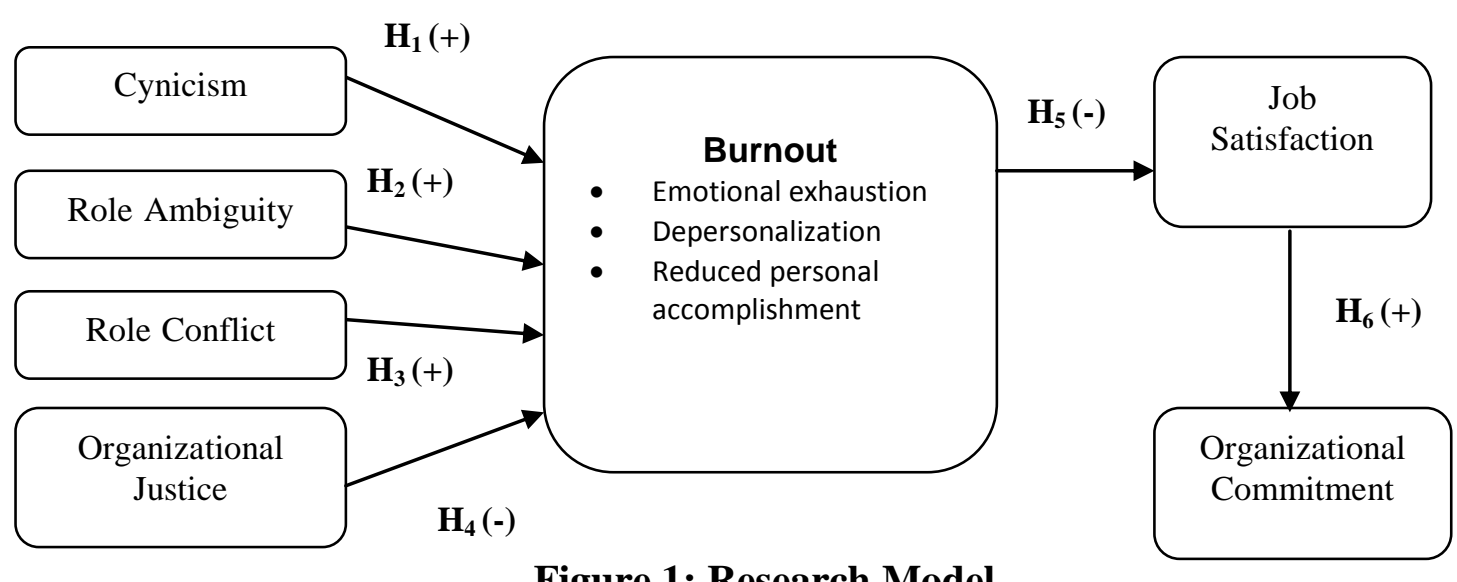

Figure 1: Research Model

\section{Reliability Analysis}

Internal reliability of the factors is calculated with Cronbach's alpha test. It is expected that the alpha value will be greater than 0.70 (Nunnally, 1978). On the other hand, if the number of variables is small, then 0.60 is acceptable for reliability (DeVellis, 2003). The obtained alpha value for the instruments used in this study can be seen in Table 3.

Table 3: Reliability Analysis

\begin{tabular}{|l|c|c|c|c|}
\hline Factors & $\begin{array}{c}\text { No. of } \\
\text { Items }\end{array}$ & Mean & Std. Dev. & $\begin{array}{c}\text { Cronbach } \\
\text { Alpha }\end{array}$ \\
\hline Emotional exhaustion & 9 & 3,05 & 0,65 & 0,661 \\
\hline Depersonalization & 5 & 2,67 & 0,75 & 0,681 \\
\hline Reduced personal accomplishment & 8 & 2,38 & 0,57 & 0,670 \\
\hline Cynicism & 7 & 3,08 & 0,81 & 0,775 \\
\hline Organizational Commitment & 5 & 2,97 & 0,80 & 0,647 \\
\hline Organizational Justice & 9 & 2,98 & 0,60 & 0,730 \\
\hline Job Satisfaction & 8 & 3,23 & 0,54 & 0,877 \\
\hline Role Ambiguity & 6 & 2,39 & 0,63 & 0,707 \\
\hline Role Conflict & 8 & 3,05 & 0,61 & 0,760 \\
\hline
\end{tabular}

According to the results obtained from Table 3, all factors in the model have sufficient reliability level for the further statistical analysis. 


\section{Correlation Analysis}

In Table 4, correlation analyses between all factors included in the research model is showed. According to the results, dimensions of burnout are positively correlated with cynicism $\left(\mathrm{H}_{1}\right)$. Role ambiguity and role conflict factors and burnout are also positively correlated $\left(\mathrm{H}_{2}\right.$ and $\left.\mathrm{H}_{3}\right)$. All dimensions of burnout have significant and negative relationship with organizational justice $\left(\mathrm{H}_{4}\right)$. As expected burnout and job satisfaction are negatively correlated $\left(\mathrm{H}_{5}\right)$. Finally job satisfaction and organizational commitments are positively correlated $\left(\mathrm{H}_{6}\right)$. As a result, all hypotheses in the research model cannot be falsified.

Table 4: Correlation Analysis

\begin{tabular}{|c|c|c|c|c|c|c|c|c|c|c|}
\hline & & $\mathrm{Ee}$ & $\mathrm{D}$ & Rpa & Cyn & Oc & $\mathrm{Oj}$ & Js & $\mathrm{Ra}$ & $\mathrm{Rc}$ \\
\hline \multirow{3}{*}{$\mathrm{Ee}$} & $\begin{array}{l}\text { Pearson } \\
\text { Correlation }\end{array}$ & 1 & 0,502 & $-0,005$ & 0,675 & $-0,494$ & $-0,405$ & $-0,393$ & 0,299 & 0,399 \\
\hline & Sig. (2-tailed) & & 0,000 & 0,921 & 0,000 & 0,000 & 0,000 & 0,000 & 0,000 & 0,000 \\
\hline & $\mathrm{N}$ & 412 & 412 & 400 & 412 & 408 & 396 & 400 & 412 & 412 \\
\hline \multirow{3}{*}{ D } & $\begin{array}{l}\text { Pearson } \\
\text { Correlation }\end{array}$ & 0,502 & 1 & 0,317 & 0,339 & $-0,210$ & $-0,119$ & $-0,227$ & 0,292 & 0,356 \\
\hline & Sig. (2-tailed) & 0,000 & & 0,000 & 0,000 & 0,000 & 0,017 & 0,000 & 0,000 & 0,000 \\
\hline & $\mathrm{N}$ & 412 & 420 & 408 & 420 & 412 & 404 & 404 & 420 & 420 \\
\hline \multirow{3}{*}{ Rpa } & $\begin{array}{l}\text { Pearson } \\
\text { Correlation }\end{array}$ & $-0,005$ & 0,317 & 1 & 0,043 & $-0,071$ & $-0,179$ & $-0,373$ & 0,479 & $-0,042$ \\
\hline & Sig. (2-tailed) & 0,921 & 0,000 & & 0,391 & 0,156 & 0,000 & 0,000 & 0,000 & 0,398 \\
\hline & $\mathrm{N}$ & 400 & 408 & 408 & 408 & 400 & 396 & 396 & 408 & 408 \\
\hline \multirow{3}{*}{ Cyn } & $\begin{array}{l}\text { Pearson } \\
\text { Correlation }\end{array}$ & 0,675 & 0,339 & 0,043 & 1 & $-0,614$ & $-0,585$ & $-0,434$ & 0,382 & 0,452 \\
\hline & Sig. (2-tailed) & 0,000 & 0,000 & 0,391 & & 0,000 & 0,000 & 0,000 & 0,000 & 0,000 \\
\hline & $\mathrm{N}$ & 412 & 420 & 408 & 420 & 412 & 404 & 404 & 420 & 420 \\
\hline \multirow{3}{*}{ Oc } & $\begin{array}{l}\text { Pearson } \\
\text { Correlation }\end{array}$ & $-0,494$ & $-0,210$ & $-0,071$ & $-0,614$ & 1 & 0,593 & 0,553 & $-0,394$ & $-0,452$ \\
\hline & Sig. (2-tailed) & 0,000 & 0,000 & 0,156 & 0,000 & & 0,000 & 0,000 & 0,000 & 0,000 \\
\hline & $\mathrm{N}$ & 408 & 412 & 400 & 412 & 412 & 400 & 400 & 412 & 412 \\
\hline \multirow{3}{*}{$\mathrm{Oj}$} & $\begin{array}{l}\text { Pearson } \\
\text { Correlation }\end{array}$ & $-0,405$ & $-0,119$ & $-0,179$ & $-0,585$ & 0,593 & 1 & 0,651 & $-0,445$ & $-0,167$ \\
\hline & Sig. (2-tailed) & 0,000 & 0,017 & 0,000 & 0,000 & 0,000 & & 0,000 & 0,000 & 0,001 \\
\hline & $\mathrm{N}$ & 396 & 404 & 396 & 404 & 400 & 404 & 392 & 404 & 404 \\
\hline \multirow{3}{*}{ Js } & $\begin{array}{l}\text { Pearson } \\
\text { Correlation }\end{array}$ & $-0,393$ & $-0,227$ & $-0,373$ & $-0,434$ & 0,553 & 0,651 & 1 & $-0,563$ & $-0,087$ \\
\hline & Sig. (2-tailed) & 0,000 & 0,000 & 0,000 & 0,000 & 0,000 & 0,000 & & 0,000 & 0,079 \\
\hline & $\mathrm{N}$ & 400 & 404 & 396 & 404 & 400 & 392 & 404 & 404 & 404 \\
\hline \multirow{3}{*}{$\mathrm{Ra}$} & $\begin{array}{l}\text { Pearson } \\
\text { Correlation }\end{array}$ & 0,299 & 0,292 & 0,479 & 0,382 & $-0,394$ & $-0,445$ & $-0,563$ & 1 & 0,184 \\
\hline & Sig. (2-tailed) & 0,000 & 0,000 & 0,000 & 0,000 & 0,000 & 0,000 & 0,000 & & 0,000 \\
\hline & $\mathrm{N}$ & 412 & 420 & 408 & 420 & 412 & 404 & 404 & 420 & 420 \\
\hline \multirow{3}{*}{ Rc } & $\begin{array}{l}\text { Pearson } \\
\text { Correlation }\end{array}$ & 0,399 & 0,356 & $-0,042$ & 0,452 & $-0,452$ & $-0,167$ & $-0,087$ & 0,184 & 1 \\
\hline & Sig. (2-tailed) & 0,000 & 0,000 & 0,398 & 0,000 & 0,000 & 0,001 & 0,079 & 0,000 & \\
\hline & $\mathrm{N}$ & 412 & 420 & 408 & 420 & 412 & 404 & 404 & 420 & 420 \\
\hline
\end{tabular}

Ee: Emotional exhaustion, D: Depersonalization, Rpa: Reduced personal accomplishment, Cyn: Cynicism, Oc: Organizational commitment, Oj: Organizational justice, Js: Job satisfaction, Ra: Role ambiguity, Rc: Role conflict 


\section{Regression Analyses}

Multiple regressions are used to explore the relationship between one continuous dependent variable and a number of independent variables or predictors. It is recommended that "for social science research, about 15 subjects per predictor are needed for a reliable equation" (Pallant, 2005, pp.140-2). In this model we have 16 independent variables $(9$ values from the research model and 7 values from demographic factors) so $16 * 15=240$ subjects are needed, nevertheless we have 420 subjects which is higher than 240 . In the Table 5, the results of regression analysis are seen. To assess the statistical significance of the result, ANOVA value should be analyzed. This value tests the null hypothesis that multiple $\mathrm{R}$ in the population equals to 0 . The model in this example reaches statistical significance (sig. $=0,000$ ). If there is a correlation between independent variables, multicollinearity exists. If the VIF (variance inflation factor) value is above 10, it indicates multicollinearity (Pallant, 2005). VIF values of independent variables are not higher than 10 (they are between 1,300 and $6,614)$, so it is concluded that there is no multicollinearity.

Beta values show the contribution of independent variables to explain the dependent variable. For example, contribution of cynicism to emotional exhaustion is $\% 50.7$. Role conflict has also positive contribution. If cynicism and role conflict values increase, then emotional exhaustion also increases. As age and income of the workers increases then emotional exhaustion will decrease.

$\mathrm{R}^{2}$ value shows how much the dependent variable is explained by the model. In the Table $5, \mathrm{R}^{2}$ value is between 0,264 and 0,498 , so independent variables in the models explain \%26.4 and \%49.8 of variance of dependent variable.

Table 5: Regression Analyses of Burnout Factors

\begin{tabular}{|c|c|c|c|}
\hline \multirow[b]{2}{*}{ Independent variables } & \multicolumn{3}{|c|}{ Dependent variables } \\
\hline & $\begin{array}{l}\text { Emotional } \\
\text { exhaustion }\end{array}$ & $\begin{array}{l}\text { Depersona- } \\
\text { lization }\end{array}$ & $\begin{array}{c}\text { Reduced } \\
\text { personal } \\
\text { accomplishment }\end{array}$ \\
\hline Cynicism & 0,507 & 0,210 & $-0,214$ \\
\hline Role ambiguity & & 0,204 & 0,507 \\
\hline Role conflict & 0,209 & 0,207 & $-0,106$ \\
\hline Organizational justice & & 0,174 & \\
\hline Age & $-0,307$ & 0,163 & 0,143 \\
\hline Number of Children & 0,092 & $-0,130$ & $-0,145$ \\
\hline Income Level & $-0,128$ & & \\
\hline Education Level & & & $-0,129$ \\
\hline Experience (in current firm) & 0,201 & 0,215 & \\
\hline \multicolumn{4}{|l|}{ Experience (in logistics sector) } \\
\hline Experience (total) & & $-0,424$ & \\
\hline $\mathrm{R}$ & 0,706 & 0,514 & 0,585 \\
\hline $\mathrm{R}^{2}$ & 0,498 & 0,264 & 0,343 \\
\hline
\end{tabular}

In the Table 6, all factors which were using the statistical analyses and demographic characteristics are shown. To find statistical differences between consumers' demographic groups and factors in the research model, some statistical tests 
were implemented by researcher. Since each group has different characteristics, the required statistical tests differ. For instance, gender and marital status were tested with independent sample t-test. Age, education level and monthly income variables tested with ANOVA or Welch test (if the homogeneity condition is not satisfied) are applied. Totally $9 * 9=81$ statistical tests were executed. After these tests, if there is a statistically significant result obtained, then with some post-hoc tests (e.g. Scheffe, Tukey, Tamhane2, etc.), the sub-groups that cause difference were found.

According to the test results, if there is a statistically significant result between demographic factors and factors in the model, than the intersection cell is signed with an " $x$ ". With this table vertical and horizontal analyses can be performed. For example while depersonalization factor differs according to all demographic factors, however job satisfaction differs only in terms of income and experience of the worker. Men's and women's perception are different in terms of depersonalization, role ambiguity and role conflict.

Table 6: Statistical Test Results of Demographic Factors

\begin{tabular}{|c|c|c|c|c|c|c|c|c|c|}
\hline & $\begin{array}{l}\overrightarrow{\bar{\theta}} \\
\overline{0} \\
\dot{0}\end{array}$ & $\underset{<}{\infty}$ & 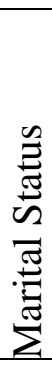 & 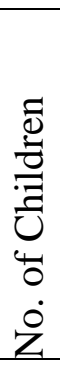 & 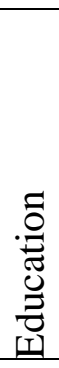 & 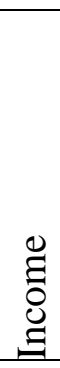 & 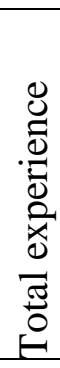 & 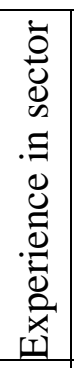 & 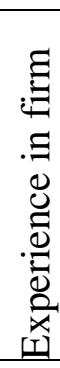 \\
\hline Emotional exhaustion & & $\mathrm{x}$ & & & $\mathrm{x}$ & & $\mathrm{x}$ & $\mathrm{x}$ & $\mathrm{x}$ \\
\hline Depersonalization & $\mathrm{x}$ & $\mathrm{x}$ & $\mathrm{x}$ & $\mathrm{x}$ & $\mathrm{x}$ & $\mathrm{x}$ & $\mathrm{x}$ & $\mathrm{x}$ & $\mathrm{x}$ \\
\hline Reduced personal accomplishment & & $\mathrm{x}$ & & $\mathrm{x}$ & & $\mathrm{x}$ & $\mathrm{x}$ & $\mathrm{x}$ & $\mathrm{x}$ \\
\hline Cynicism & & $\mathrm{x}$ & & $\mathrm{x}$ & $\mathrm{x}$ & & $\mathrm{x}$ & $\mathrm{x}$ & $\mathrm{x}$ \\
\hline Role ambiguity & $\mathrm{x}$ & & & & & $\mathrm{x}$ & $\mathrm{x}$ & $\mathrm{x}$ & $\mathrm{x}$ \\
\hline Role conflict & $\mathrm{x}$ & $\mathrm{x}$ & & $\mathrm{x}$ & $\mathrm{x}$ & $\mathrm{x}$ & $\mathrm{x}$ & $\mathrm{x}$ & $\mathrm{x}$ \\
\hline Organizational justice & & $\mathrm{x}$ & & & $\mathrm{x}$ & & $\mathrm{x}$ & $\mathrm{x}$ & $\mathrm{x}$ \\
\hline Organizational commitment & & $\mathrm{x}$ & $\mathrm{x}$ & & $\mathrm{x}$ & $\mathrm{x}$ & $\mathrm{x}$ & $\mathrm{x}$ & $\mathrm{x}$ \\
\hline Job satisfaction & & & & & & $\mathrm{x}$ & $\mathrm{x}$ & $\mathrm{x}$ & $\mathrm{x}$ \\
\hline
\end{tabular}

According to the post-hoc tests, men's depersonalization, role ambiguity and role conflict levels are higher than women's. Single workers have more depersonalization and organizational commitment level than married workers. If the education level gets higher than cynicism and role conflict level increase and organizational justice level decreases. When the income of the workers raises their job satisfaction and organizational commitment level get higher however their reduced personal accomplishment falls. When the workers get older, their reduced personal accomplishment and cynicism level will decrease.

\section{Conclusion}

This study draws attention to the importance of burnout on workers' organizational commitment level in the logistics companies. The most valuable assets of all businesses are their employees. Employees also are considered as internal customers. In particular workers in the service sector have more importance. Logistics sector is 
among the sectors that require dense personal relationships with customers. Although there are many academic studies about logistics sector's operational areas, the psychological status of employees and their satisfaction level about their work was underrated. The most important work-related psychological problem of employees is burnout. Burnout is an important problem for workers that cause many distresses not only in their professional life but also in their private lives.

In this study, factors which force employees to burnout have been studied. Literature review shows that organizational justice, role ambiguity, role conflict and cynicism are the most important organizational reasons for burnout. With statistical analyzes, the impact of factors on burnout have been revealed. One of the most important problems employees encounter as a result of burnout is a drop in job satisfaction, but also a significant decrease will be observed in organizational commitment. Logistics activities which consist of activities significantly depending on human relations will be influenced from the fall in the commitment of employees.

The survey data used in the study have been obtained from 420 employees who work at the logistics companies in Istanbul-Turkey. Employees are demographically in different age, education and income groups. Another variable used in the analysis has been work experience of employees.

In the correlation analysis, all the hypotheses shown in the research model cannot be falsified. As a result of regression analysis, the effects of three dimensions of burnout on the variables in the model are shown. According to the results obtained, as time worked at the company increases then burnout level also tends to rise. Burnout is inversely correlated with employee's income but directly correlated with cynicism, role conflict and role ambiguity factors

As a result, the most important variables that cause burnout between employees are management originated, and businesses would significantly prevent this situation by taking small preventive interventions.

\section{References}

Adekola, B. 2012. "Work Burnout Experience among University Non Teaching Staff: A Gender Approach". International Journal of Academic Research in Business and Social Sciences 2 (1): 128-135.

A1 Zahrani, A. 2011. "The Impact of Organizational Justice on Job Burnout: A Study In Private Hospitals In Riyadh, Saudi Arabia". Interdisciplinary Journal of Contemporary Research In Business 3 (6): 627-637.

Bateman, T.S., and S. Strasser. 1984. "A Longitudinal Analysis of the Antecedents of Organizational Commitment". The Academy of Management Journal 27 (1): 95112.

Cherniss, C. 1992. "Long-Term Consequences of Burnout: An Exploratory Study". Journal of Organizational Behaviour 13 (1): 1-11.

Dean, J. W., P. Brandes, and R. Dharwadkar. 1998. "Organizational Cynicism", Academy of Management Review 23 (2): 341-52.

DeVellis, F. R. 2003. Scale Development: Theory and Applications, Thousand Oaks, CA: Sage Publication. 
Elamin, A. M. and N. Alomaim. 2011. "Does Organizational Justice Influence Job Satisfaction and Self-Perceived Performance in Saudi Arabia Work Environment?". International Management Review 7 (1): 38-49.

Greenberg, J. 1987. "A taxonomy of organizational justice theories". Academy of Management Review 12 (1): 9-22.

Hultell, D., and J. P. Gustavsson. 2010. "A psychometric evaluation of the Scale of Work Engagement and Burnout (SWEBO)". Work 37: 261-274.

Jaworski, B. J., and K. A. Kohli. 1993. "Market Orientation: Antecedents and Consequences". Journal of Marketing 57: 53-70.

Karacaoğlu, K., and F. İnce. 2012. "Brandes, Dharwadkar ve Dean'in (1999) Örgütsel Sinizm Ölçeği Türkçe Formunun Geçerlilik ve Güvenilirlik Çalışması: Kayseri Organize Sanayi Bölgesi Örneği”. Business and Economics Research Journal 3 (3): 77-92.

Kristensen, T.S., M. Borritz, E. Villadsen, and K.B. Christensen. 2005. "The Copenhagen Burnout Inventory: A new tool for the assessment of burnout". Work \& Stress 19 (3): 192-207.

Kumari, G., and K. M. Pandey. 2011. "Job Satisfaction in Public Sector and Private Sector: A Comparison". International Journal of Innovation, Management and Technology 2 (3): 222-228.

Kuruüzüm, A., N. Anafarta, and S, Irmak. 2008. "Predictors of burnout among middle managers in the Turkish hospitality industry". International Journal of Contemporary Hospitality Management 20 (2): 186-198.

Lee, J. 2001. "Leader-member exchange, perceived organizational justice, and cooperative communication". Management Communication Quarterly 14: 574589.

Low, G. S., D. W. Cravens, K. Grant, and W. C. Moncrief. 2001. "Antecedents and consequences of salesperson burnout". European Journal of Marketing 35 (5/6): 587-611.

Maroco, J., and J. A. D. B. Campos. 2012. "Defining the student burnout construct: A structural analysis from three burnout inventories". Psychological Reports: Human Resources \& Marketing 111 (3): 814-830.

Maslach, C., and S. E. Jackson. 1981. "The measurement of Experienced Burnout". Journal of Occupational Behaviour 2: 99-113.

Meyer, J. P., and N. J. Allen. 1991. "A Three-component conceptualization of organizational commitment: Some methodological considerations". Human Resource Management Review 1: 61-98.

Moorman, R. H. 1991. "Relation between organizational justice and orgtanizational citizenship behaviours: does fairness perception influence employee citizenship?". Journal of Applied Psychology 76 (6): 845-855.

Niehoff, B. P., and R. H. Moorman. 1993. "Justice as a mediator of the relationship between methods of monitoring and organizational citizenship behaviour". Academy of Management Journal 36 (3): 527-556.

Nunnally, J. 1978. Psychometric Theory. New York, McGraw-Hill. $2^{\text {nd }}$ edition.

Pallant, J. 2005. SPSS Survival Manual A step by step guide to data analysis using SPSS for Windows (Version12). Allen \& Unwin, Australia. $2^{\text {nd }}$ edition. 
Salahian, A., H. R. Oreizi, M. R. Abedi, and I. Soltani. 2012. "Burnout and Relevant Factors in Organization". Interdisciplinary Journal of Contemporary Research Business 3 (12): 551-558.

Schleicher, D. J., J. D. Watt, and G. J. Greguras. 2004. "Reexamining the Job Satisfaction - Performance Relationship: The Complexity of Attitudes". Journal of Applied Psychology 89 (1): 165-177.

Tang, Y. T., and C. H. Chang. 2010. "Impact of role ambiguity and role conflict on employee creativity". African Journal of Business Management 4 (6): 869-881.

Volker, R., B. Bernhard, K. Anna, S. Fabrizio, R. Robin, P. Jessica, S. Rudolf, D. Lucia, R. Jürgon, H. Franz, S. Christine, and S. Norbert. 2010. "Burnout,Coping and Job Satisfaction in Service Staff Treating Opioid Addicts-from Athens to Zurich".Stress and Health 26: 149-159. 